\title{
Dari Spiritualitas kepada Moralitas: Pelajaran Kepemimpinan dari Kehidupan Yusuf
}

\author{
Fredy Simanjuntak ${ }^{1}$, Irfan F. Simanjuntak ${ }^{2}$, Fransiskus Irwan Widjaja ${ }^{3}$, Yudhy Sanjaya ${ }^{4}$, \\ Johannes Tarigan 5 \\ Sekolah Tinggi Teologi Real Batam \\ Email:fredygrace@gmail.com
}

\begin{abstract}
In the History of Ancient leadership, the Old Testament is a collection of books containing narratives with the largest collection of leadership case studies ever written. The author observes the significance of biblical leadership found throughout scripture because it is rooted in the way God chose to work with mankind. However, the role of leadership is undeniably determining the welfare and glory of those they lead. In this study, the author tries to specifically examine Yusuf's leadership. A leadership pattern that is widely discussed because it is full of spiritual and moral dimensions. The purpose of this study is to provide a historical analysis of (1) Spirituality and morality in Yusuf's leadership. (2) Application of Joseph's Leadership Experience to the Church Today? The method used is descriptive analysis in the book of Genesis 37-50. The result of this research is that Yusuf's leadership can be a model as a good lesson not only for individuals in leadership positions but for all those who want to improve their character.
\end{abstract}

Keywords: Spirituality, Morality, Leadership, Joseph, Old Testament.

\begin{abstract}
Abstrak
Dalam Sejarah kepemimpinan Kuno, kitab Perjanjian Lama merupakan kumpulan kitab yang berisi narasi dengan berbagai kumpulan studi kasus kepemimpinan terbesar yang pernah ditulis. Penulis mengamati signifikansi kepemimpinan alkitabiah ditemukan di seluruh kitab suci karena berakar pada cara Allah memilih untuk bekerja dengan umat manusia. Bagaimanapun peranan kepemimpinan tidak terbantahkan menentukan perihal kesejahteraan maupun kejayaan mereka yang dipimpin. Dalam Penelitian ini penulis mencoba untuk mengkaji secara khusus kepemimpinan Yusuf. Suatu pola kepemimpinan yang banyak dibicarakan karena sarat akan dimensi spiritual dan moralnya. Tujuan penelitian ini untuk memberikan analisis historis mengenai (1) Spiritualitas dan moralitas dalam kepemimpinan Yusuf. (2) Aplikasi dari Pengalaman Kepemimpinan Yusuf Bagi Gereja Di Masa Kini. Metode yang digunakan adalah analisis deskriptif pada kitab Kejadian 37-50. Hasil penelitian ini adalah kepemimpinan Yusuf menjadi model berharga sebagai pelajaran yang baik bukan hanya bagi individu dalam posisi kepemimpinan tetapi semua orang yang ingin meningkatkan karakter mereka.
\end{abstract}

Kata-kata kunci: Kepemimpinan; Moralitas; Perjanjian Lama; Spiritualitas; Yusuf. 


\section{PENDAHULUAN}

Kisah-kisah dalam Perjanjian Lama mencatat begitu banyak tokoh-tokoh yang berperan dalam sejarah kepemimpinan, mulai dari kepemimpinan keluarga, suku, bahkan kerajaan. Sekalipun pemimpinpemimpin ini begitu penting, faktanya Alkitab dengan begitu terbuka tidak pernah menyembunyikan kesalahan yang dibuat oleh orang-orang hebat tersebut. Kepemimpinan silih berganti sebagai tanda cara Allah memilih untuk bekerja dengan umat manusia. Ini menjadikan keunikan kitab suci dalam memberikan pelajaran berharga untuk mengajarkan karakter moral. Dalam hal ini penulis mencoba mengkaji lebih dalam sisi yang jarang dipaparkan secara menyeluruh karakter maupun spiritualitas dari kepemimpinan seorang Yusuf.

Yusuf, dalam Perjanjian Lama adalah putra dari Yakub dari istrinya Rahel. Karena nama Yakub menjadi sinonim dengan seluruh Israel, demikian pula nama Yusuf akhirnya disamakan dengan semua suku yang membentuk kerajaan utara. Menurut tradisi, tulang-tulangnya dikuburkan di Sikhem, kuil tertua di utara (Yosua 24:32). Kisahnya diceritakan dalam Kejadian (37$50)$.
Yusuf adalah salah satu karakter favorit sekaligus pemimpin yang sukses yang terbukti memiliki spiritualitas yang seimbang dengan moralitasnya, terlepas kisah perjalanan hidupnya mengalami kecemburuan, penipuan, perbudakan, penggambaran yang salah, ketidakadilan, nafsu, persaingan, dan pengampunan. Namun pada akhirnya Yusuf tampil sebagai pemimpin yang teruji di Mesir. Hal ini menunjukkan contoh yang luar biasa tentang bagaimana Tuhan bekerja dalam kehidupan Yusuf melalui semua kondisi pergumulan hidup dan pasang surutnya. Akhir kisah Yusuf menunjukkan akhir dengan kisah kebahagiaan melalui pelbagai penderitaan yang Tuhan ijinkan sebagaimana tertulis dalam Pengkhotbah (3:11; Roma 8:28).

Menariknya, jika dibandingkan dengan kepemimpinan modern, begitu banyak kepemimpinan yang kuat dalam hal spiritualitas namun tak jarang sarat akan skandal dan tergelincir dalam masalah moral, bahkan dalam kepemimpinan gereja sekalipun tidak sedikit ditemukan isu-isu demikian. Pemimpin yang baik tidak cukup hanya memiliki spiritualitas yang baik namun juga harus diimbangi dengan moralitas yang baik juga, memiliki karakter moral, etis dan melakukan hal yang benar 
bahkan sekalipun tidak ada orang yang melihat dan tidak ada cara untuk ketahuan.

Berdasarkan latar belakang penelitian di atas, penulis juga memaparkan beberapa penelitian sebelumnya, Dedy Riswanto yang membahas tentang prinsipprinsip kepemimpinan Yusuf (Riswanto \& Djadi, 2010). Kajian lain yang dilakukan oleh Susanto Dwiraharjo mengenai kepemimpinan Yusuf sekaligus panggilan Allah atasnya (Dwiraharjo, 2018). Sementara hasil penelitian ini hendak menjelaskan aspek spiritualitas dan moralitas yang begitu melekat kuat dalam kepemimpinan Yusuf. Perbedaan penelitian ini dengan penelitian yang dilakukan oleh Dedy Riswanto adalah untuk membuktikan pelajaran kepemimpinan yang ideal memiliki tolok ukur moral dan spiritual yang seimbang. Melalui kajian ini akan diperiksa bagaimana proses kepemimpinan dibentuk melalui integritas dan karakter yang teruji.

Penulis ingin melihat beberapa hal yang dirumuskan melalui pertanyaanpertanyaan berikut: (1) Bagaimana Realitas Spiritualitas dan moralitas Yusuf? (2) Bagaimana Gereja mengaplikasikan prinsip kepemimpinan Yusuf dalam masa kini? Beranjak dari rumusan masalah, penelitian ini bertujuan (1) untuk memeriksa realitas spiritualitas dan moralitas pribadi Yusuf dalam Perjanjian Lama (2) Mengaplikasikan prinsip kepemimpinan Yusuf untuk mengembangkan cetak biru kepemimpinan yang seimbang yang relevan diberbagai lini.

\section{METODE PENELITIAN}

Penulisan paper ini dilakukan dengan menggunakan metode kualitatif. Pengumpulan data dalam tulisan ini merupakan kajian literatur teks Alkitab Perjanjian Lama dan buku-buku Referensi. Dengan studi kepustakaan, penulis berusaha mencari data dari Kitab Suci dan buku-buku yang berkaitan dengan pokok penelitian, agar tulisan ini dapat membuktikan dan mengembangkan sejarah yang berhubungan dengan pokok penelitian. Pendekatan pencarian teks Alkitab dilakukan dengan menggunakan pendekatan secara tekstual sehingga dapat mengungkap makna-makna kepemimpinan Yusuf yang diasosiasikan dengan karakter spiritual dan moral Yusuf berdasarkan kitab Perjanjian Lama. Kajian secara tekstual kemudian digunakan untuk menghubungkan ayat-ayat yang berkaitan sehingga memperoleh hasil yang baik. Dalam penafsiran Kitab Suci membutuhkan analisis dan tafsiran Kitab Suci dan sejarah sehingga penafsiran bisa terjadi dan mendapat hasil yang maksimal. Berdasarkan proses penelitian tersebut di dapatkan hasil 
makna Kepemimpinan Yusuf berdasarkan Perjanjian Lama yang di deskripsikan secara perpoint. Terutama mengacu pada keseimbangan spiritual dan moral yang tercermin dalam diri Yusuf.

\section{PEMBAHASAN DAN HASIL}

\section{Pengertian Spiritualitas}

Secara menyeluruh isi Kejadian 3750 adalah satu cerita, jadi orang harus benarbenar mempertimbangkan keseluruhan narasi sebagai satu kesatuan. Banyak sisi yang dapat diambil dari penjabaran suatu cerita. Tetapi tentu saja sangat tidak mungkin apabila dalam satu tulisan pendek dapat menyingkapkan semua sisi secara bersamasama. Oleh sebab itu pada bagian ini hanya ingin menyingkapkan rahasia spiritualitas Yusuf berpadanan dengan moralitasnya di hadapan Allah dalam konteks kepemimpinan.

Spiritualitas adalah kekuatan yang membantu seseorang membangun dirinya secara utuh. Kecerdasan spiritual berasal dari dalam hati, membuat seseorang menjadi kreatif ketika dihadapkan pada masalah pribadi, dan memiliki kemampuan melihat makna yang terkandung di dalamnya berdasarkan ajaran agama, serta menyelesaikannya dengan baik agar memperoleh ketenangan dan kedamaian hati.
Spiritualitas membuat inividu mampu memaknai setiap kegiatannya sebagai suatu ibadah (Purwanto, 2020). Fredy Simanjuntak dkk menambahkan Spritualitas adalah nilai atau pemahaman yang dimiliki oleh manusia dalam berperilaku satu dengan yang lainya bahkan hubungan dengan Tuhan yang dipengaruhi oleh lingkungan hidup, pengalaman dan pengetahuan. Setiap manusia memiliki spiritualitas dalam dirinya, dan spritiualitas mempengaruhi baik buruknya perilaku individu ditengah-tengah masyarakat atau terhadap individu lainnya (Simanjuntak et al., 2018).

Sementara Kenneth I. Pargament dalam Margot Hover menyatakan Spiritualitas adalah "pencarian yang suci" (Hover, 1999) dan "berkaitan dengan jalan yang diambil orang dalam upaya mereka untuk menemukan, melestarikan, dan mengubah yang suci dalam hidup mereka"(Zinnbauer et al., 1999).

Berbagai penulis yang berusaha mendefinisikannya telah menekankan pada aspek-aspek seperti perasaan terhubung atau menjadi bagian dari alam semesta, percaya pada kekuatan di luar diri seseorang, mencari rasa makna atau tujuan, mengalami transendensi, mencari kebenaran tertinggi dan pribadi seseorang, mengetahui persatuan dari kasat mata dan tidak kasat mata, 
memiliki hubungan yang terinternalisasi antara individu dan ilahi, menjumpai cinta tanpa batas, dan bergerak menuju keutuhan pribadi (Decker, 1993; Ganje-Fling \& McCarthy, 1996; King et al., 1995; Shafranske, 1996; Sharma et al., 2009).

\section{Spiritualitas Yusuf}

Yusuf mengalami masa kegelapan, ketika dia dibuang, dia dapat tinggal di rumah Potifar, namun kali ini dia harus tinggal di penjara di saat keberhasilan yang dia raih dan fitnahan yang harus dia terima demi menjaga kesucian di hadapan Allah. Ketika Yusuf berhasil bangkit, ini merupakan karya Allah dan mentalitas Yusuf semakin bertambah kuat (Hendi, 2017). Hal ini sesuai dengan pemaparan Martin Luther yang menyatakan bahwa ini tentu saja merupakan contoh dari pekerjaan Tuhan, bagaimana Ia meninggikan orang-orang kudus-Nya, sehingga dalam pencobaan mereka belajar kesabaran dalam iman dan harapan, meskipun harapan adalah benarbenar kesabaran itu sendiri, dan bagaimana seseorang tetap dapat mempertahankankan dirinya dengan Firman Allah bukan hanya di dalam keadaan bahaya ataupun konfik, tetapi juga dalam doktrin Kristen (Luther, 2007). Dalam Perjanjian Lama, Tuhan sering membiarkan penderitaan mendidik umat-
Nya. Widjaja dkk menegaskan "In the Old Testament, God often allowed suffering to educate his people. Suffering provides space for critical reflection on the spiritual struggles of God's people" (Widjaja et al., 2021).

Dalam riset yang telah dilakukan oleh Graham Jones dkk terhadap beberapa orang yang berprofesi sebagai atlit olahraga, psikolog serta sejumlah pelatih olahraga yang menemukan sebuah kesimpulan yang terkait dengan ketangguhan mental adalah keunggulan psikologis alami yang dimiliki oleh seseorang sehingga dapat mengatasi berbagai tuntutan (kompetisi, pelatihan, gaya hidup) dan teguh dalam tekad, fokus, percaya diri, dan terkendali di bawah tekanan" (Jones et al., 2002). Sedikitnya ada empat Ada 4 aspek yang menjadi indikator ketahanan mental ini yakni, "satu dimensi umum digariskan: sikap atau pola pikir pelaku (khususnya, fokus dan kepercayaan diri pelaku). Tiga dimensi spesifik waktu diuraikan: pelatihan, kompetisi, dan pascakompetisi. Dimensi spesifik waktu ini berisi atribut ketangguhan mental (seperti menangani tekanan, menangani kegagalan, dan mendorong diri Anda sendiri hingga batas fisik Anda dalam pelatihan) yang berkaitan dengan penggunaannya pada saatsaat ini” (Jones et al., 2007). Yusuf 
mengalami peristiwa hebat yang berat: kecemburuan, penipuan, perbudakan, penggambaran yang salah, ketidakadilan namun mampu memehuhi empat aspek dimensi daya tahan mental. Yusuf memiliki sikap yang fokus dan percaya diri, menangani tekanan, menangani kegagalan dan mendorong dirinya ke batas fisiknya.

Menurut Cindy Wigglesworth kecerdasan spiritual, didefinisikan sebagai kemampuan untuk berperilaku dengan kebijaksanaan dan kasih sayang, dengan tetap menjaga kedamaian lahir dan batin, terlepas dari situasinya (Wigglesworth, 2006). Dengan kata lain orang yang memiliki daya tahan mental yang kuat merupakan orang yang memiliki spiritualitas yang baik. Lebih lanjut lagi Wigglesworth menuliskan, ada 21 keterampilan yang masuk di dalam SQ termasuk "bertanggunjawab atas diri sendiri sepenuhnya"(Wigglesworth, 2006). Yusuf memiliki mental "pertanggungjawaban diri yang baik." Wigglesworth menyatakan, "Pengembangan SQ bermuara pada peralihan dari perilaku yang didorong oleh ego yang belum matang ke perilaku yang didorong oleh diri sendiri yang lebih dewasa." Wigglesworth menjelaskan bagaimana seseorang melakukan hal tersebut, "ini merupakan upaya diri untuk mengembangkan kemampuan mendengar suara nurani yang lebih tinggi, untuk memahami dan melampaui suara ego, dan untuk dibimbing oleh kebijaksanaan dan kasih sayang yang mendalam. Ego yang matang mendorong pembentukan kepemimpinan yang lebih efektif berkembang" (Wigglesworth, 2006). Dalam konteks kehidupan Yusuf jelaslah terlihat bahwa ia memiliki kecenderungan menuruti pimpinan Allah yang membuatnya penuh kebijaksanaan dan selalu disertai Allah dalam kesuksesan.

Bahkan dalam keterpurukan sekalipun ketika Yusuf dipenjara, mentalnya bukan bertambah melemah, penyertaan Allah tidak pernah berkurang dalam hidupnya. Spiritualitas yang ada pada diri Yusuf ternyata juga membuat dirinya memiliki sikap mengendalikan emosinya dengan baik. Sebagaimana dijelaskan sebelumnya di atas bahwa ketahanan mental dan kesabaran serta kerja keras berjalan secara linier dengan kedalaman spiritualitas Yusuf. Keberhasilan Yusuf dalam penjara menunjukkan didikan kepada Yusuf sehingga ia memiliki ketangguhan seperti yang dikatakan oleh Luther,

Karena itu, hingga saat ini, dia berjalan seperti orang buta dalam kegelapan yang paling pekat. Dia tidak melihat Tuhan atau ayahnya atau apapun selain kematian dan kehancuran. Tetapi dia berpegang 
teguh pada Firman yang dia dengar dari ayahnya: "Akulah Tuhan, Allahmu, dan Allah nenek moyangmu." Firman ini telah menjadi hidupnya, dan dari kehidupan ini dia nantinya akan dibangkitkan kepada kemuliaan dan kehormatan yang tak terukur (Luther, 2007:106).

\section{Moralitas Yusuf}

Kitab Kejadian mencatat serangkaian ancaman berulang yang membahayakan kelangsungan hidup dan kemurnian garis perjanjian Allah dengan keturunan Abraham. Dalam bab 37-50, semua ancaman bertemu, menciptakan situasi yang sangat mengerikan bagi Yakub dan anak-anaknya. Dalam suatu peristiwa Yusuf melaporkan kejahatan saudara-saudaranya kepada Ayahnya.

Inilah riwayat keturunan Yakub. Yusuf, tatkala berumur tujuh belas tahun--jadi masih muda--biasa menggembalakan kambing domba, bersama-sama dengan saudara-saudaranya, anak-anak Bilha dan Zilpa, kedua isteri ayahnya. Dan Yusuf menyampaikan kepada ayahnya kabar tentang kejahatan saudarasaudaranya (Kejadian 37:2).

Dalam komentarnya Kenneth A. Matthews menjelaskan dengan tepat bahwa, "Ayat ini memiliki anggota paralel, mengomentari statusnya dalam keluarga.

A Yusuf berumur 17 tahun

B sedang menggembalakan kawanan domba bersama saudara-saudaranya

$\mathrm{A}^{\prime}$ dan dia adalah seorang pemuda

$\mathrm{B}^{\prime}$ dengan anak-anak Bilha dan anakanak Zilpa, istri-istri ayahnya
C dan Yusuf membawa laporan buruk kepada ayah mereka" (Mathews, 2007).

Penjelasan Matthews merujuk Bagian A dan A' mengenai sosok Yusuf sebagai anak muda dan B dan B' mengkondisikan Yusuf di tengah-tengah saudara-saudaranya. Pada bagian C menunjukkan bagaimana Yusuf konflik dengan saudara-saudaranya.

Dalam Penjelasan teks di atas dikatakan bahwa Yusuf turut bekerja sebagai gembala Bersama saudara-saudaranya. Namun ada perbedaan yang menarik yang dimiliki oleh Yusuf muda dengan kakakkakaknya, Yusuf mengerti dan sadar akan perbuatan jahat saudara-saudaranya. Verba

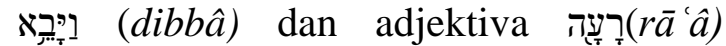
menunjukkan kesan yang negatif sebagaimana dijelaskan dalam kutipan Matthews berikut, biasanya muncul dalam konteks yang meremehkan (misalnya, matamata, Bil 13:32), menunjukkan bahwa laporan tersebut merendahkan. Sifat "laporan" secara umum digambarkan sebagai "buruk (rā'â, i.e., “evil’). Kelompok kata r'-h adalah kata kunci yang berulang dalam Kejadian (mis., 6:5). Ini menandakan "laporan" terakhir Yusuf tentang tindakan saudara-saudaranya, "Kamu bermaksud mencelakakan [rā'â] aku, tetapi Allah bermaksud untuk kebaikan [țōbâ]" (50:20). 
Tuhan akan mengubah "laporan buruk" Yusuf tentang saudara-saudaranya menjadi hasil yang "baik" bagi keluarga dan seterusnya. Namun, dalam adegan langsung, "laporan [rā'â] yang buruk" membayangi masa depan Yusuf, karena istilah yang sama menggambarkan "binatang [rā'â] yang dianggap ganas" (ay. 20, 33) yang melahapnya (Mathews, 2007:688).

Puncak konflik antara Yusuf dengan saudara-saudaranya tampak di ayat 3 setelah Yusuf melaporkan kejahatan saudarasaudaranya kepada Yakub. Kisah Yusuf di antara saudara-saudaranya tampak menonjolkan tanda favorit dan konflik yang menggambarkan kisah Yusuf dalam keluarganya.

Perbuatan Yusuf mengindikasikan moralitas Yusuf yang baik dalam usia yang muda. Dalam Narasi Kej 37:2 memberikan penjelasan akan ketidak terlibatan diri Yusuf dengan saudara-saudaranya. Yusuf memiliki spiritualitas yang baik seperti yang dikatakan oleh Michele Borba, kemampuan Yusuf yang kuat dalam hal tika yang tampak pada perbuatannya dengan melaporkan kepada Ayahnya perbuatan jahat saudarasaudaranya bukan hanya menunjukkan bahwa ia mampu membedakan perbuatan salah dan benar namun juga berani (Borba, 2001:74-75).
Kunci penting dalam pasal 37:2 kitab Kejadian memberikan penjelasan yang menarik dari sisi moralitas Yusuf dalam kemampuannya membedakan yang benar dan salah. Spiritualitas ini akan diperiksa sebagai penentu keberhasilan Yusuf kelak. Moralitas sebagai dasar kesadaran bagi seluruh manusia dalam berbuat sesuatu yang baik, bermakna dan bermanfaat. Moralitas sebagai dasar kesadaran bagi seluruh manusia dalam berbuat sesuatu yang baik, bermakna dan bermanfaat. Moralitas mendorong seseorang dalam mencapai tujuan hidup yang memberikan pengetahuan sekaligus alasan atas apa yang dikerjakannya. Makna hidup akan tampak kabur tanpa moralitas. Hal ini memberikan manusia kemampuan untuk memahami hal yang benar dan salah dan memiliki keyakinan yang kuat dalam bertindak secara tepat secara benar dan terhormat. Hal ini sesuai dengan penjelasan Kalis Stevanus Orang yang berkarakter pasti tidak akan melakukan hal-hal yang diketahuinya salah, karena hal itu bertentangan dengan imannya dan juga suara hatinya yang telah diterangi oleh firman Tuhan (Stevanus, 2018:94). Moralitas mendorong seseorang dalam mencapai tujuan hidup yang memberikan pengetahuan sekaligus alasan atas apa yang dikerjakannya. Makna hidup akan tampak 
kabur tanpa moralitas. Hal ini memberikan manusia kemampuan untuk memahami hal yang benar dan salah dan memiliki keyakinan yang kuat dalam bertindak secara tepat secara benar dan terhormat.

Kejadian 39:2-23 menceritakan kisah istri Yusuf dan Potifar. Ini adalah kisah yang kuat, dan bukan hanya karena Yusuf sebagai seorang pemuda menolak ajakan seksual istri bosnya. Kisah luar yang jelas itu telah memunculkan sejumlah khotbah moral tentang kemurnian: pengendalian diri, respon, lari. Sebaliknya, jika dipertimbangkan tema utama dari keseluruhan narasi perlindungan Allah atas Yusuf untuk menyelamatkan keluarga Yusuf barangkali akan mendapati pesan yang lebih dalam, pesan yang dapat diidentifikasi pribadi seorang Yusuf sebagai manusia nyata yang menghadapi pergumulan dan godaan. Kitab Suci mencatat bagaimana Yusuf tetap mempertahankan integritasnya di hadapan Allah.

Peristiwa Yusuf menolak ajakan tidur dan bersetubuh dengan isteri Potifar membuktikan bahwa dia memiliki keyakinan moral yang kuat (39: 6b-19). (Matthew, 2005:734) Pasal 39: 9b menyatakan pertanyaan retoris yang mendukung iman yang kokoh dari Yusuf di tengah budaya yang tidak mengenal Allahnya Yusuf.
Matthews dengan tepat menjelaskan, pertanyaan retorika Yusuf mencapai level etika tertinggi: "Bagaimana ... saya bisa melakukan hal yang jahat dan berdosa terhadap Tuhan?" (ay.9). Pertanyaan retoris menyoroti absurditas mempertimbangkan pelanggaran perilaku moral semacam itu. Bahasa Ibrani "kejahatan besar ini" ("hal yang begitu jahat," NIV) memiliki efek yang sama dalam menggarisbawahi kebejatan saran terlarangnya (bdk. "kesalahan besar ini" pada komentar pada 20:9). "Kejahatan" $\left(r \bar{a}{ }^{\prime} \hat{a}\right)$ juga menggambarkan kasih sayang mental masyarakat pradiluvia (6:5), dan hukuman mati Musa-lah yang menyingkirkan (rā'â) jahat dari Israel" (Ulangan 22:22). Tetapi kejahatan itu tidak hanya terhadap Potifar; Yusuf mengerti bahwa pelanggaran ini menyakiti hati Tuhan sendiri. Pengakuan Daud mengakui hal yang sama (Mzm 51:4[6]). Hukum Musa menuntut kematian pelaku perzinahan (Im 20:10; Ul 22:22) karena hal itu dipandang sebagai pelanggaran terhadap Tuhan dan bukan terhadap pasangannya saja. Kode hukum tetangga Israel mengizinkan hukuman mati juga (lih. komentar pada 20:9) tetapi sering kali memasukkan ketentuan khusus di mana pasangan yang tersinggung dapat mengampuni pelaku kesalahan. Outline dari Matthews di atas 
memperlihatkan bahwa penolakan Yusuf terhadap godaan ini merupakan inti dari pasal 39. Yusuf digoda dan dia mampu mempertahankan integritas moral di hadapan

Allah. Marthin Luther menyatakan

Karena wanita seperti itu menarik dan mengobarkan hati. Tetapi untuk mengatasi godaan ini Yusuf menjaga perintah Allah di depan mata dengan keteguhan yang besar; dan ketika dia melihat bahwa tidak ada obat yang dapat diterapkan untuk menekan kemarahan nyonya rumah, dia melakukan semua yang dia bisa untuk memisahkan dirinya darinya, menghindari kesempatan untuk bergaul dan berbicara dengannya, dan menutup setiap pendekatan untuk dirinya sendiri (Luther, 2007:86).

Yusuf mengerti bahwa godaan seksual dari isteri Potifar dapat menjebak dia berbuat dosa di hadapan Allah. Bagi Yusuf adalah lebih penting mempertahankan hidup yang kudus di hadapan Allah daripada menikmati kenikmatan sesaat. Kesucian mendatangkan penyertaan Allah dan di tengah pengalaman penderitan kembali Tuhan menyertai Yusuf sehingga ia berhasil. Ini merupakan aspek kecerdasan moral yang dimiliki Yusuf.

Spiritualitas yang dilatih secara terus menerus menjadikan Yusuf memiliki karakter, sikap dan moral yang sangat luar biasa, baik di hadapan Tuhan maupun manusia. Kecerdasan Spiritualnya menjadikan Yusuf sebagai seorang yang takut akan Tuhan dan sungguh-sungguh dalam menjaga kekudusan hidupnya (Purwanto, 2020).

Allah "menyertai," dan menunjukkan ịn, "kebaikan", berulang kembali (selain ayat 2, 3, 4) untuk menunjukkan peny.ertaan Allah tidak meninggalkan Yusuf bahkan Ketika ia berada di dalam penjara sekalipun. Oleh karena itu, dalam teks ini "Tuhan menyertai Yusuf'-penuh dengan penghiburan dan sukacita. Karena meskipun dia belum dibebaskan, Tuhan tetap berpikir untuk membangkitkan dia dari kematian dan neraka setelah darahnya cukup lama menangis ke surga (Kej. 4:10) dan telah mewujudkannya bahwa Tuhan menjadi Pemelihara Jiwanya dan mencondongkan rahmat-Nya kepadanya (Luther, 2007:100).

Dan Matthews menyatakan, "Penggabungan keterlibatan manusia dan syafaat ilahi ini mencerminkan teologi penulis, karena pada akhirnya Tuhanlah yang mendorong Potifar untuk memberikan hak istimewa khusus kepada Yusuf" (Matthew, 2005:738). Kebikan dan penyertaan Allah menjadi sukacita dan hak istimewa bagi Yusuf sehingga ia mampu untuk bangkit meskipun nama baik atau reputasinya dihancurkan oleh orang lain. 
Segera di dalam Penjara Yusuf mendapatkan kepercayaan kepala penjara sebagaimana ia di rumah Potifar. Yusuf bahkan dipercayakan untuk mengurus semua tahanan lain di dalam penjara tanpa campur tangan dari kepala penjara bahkan dalam pekerjaan itupun kitab suci mengatakan

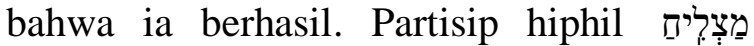
kembali digunakan untuk menunjukkan keberhasilan Yusuf merupakan campur tangan Allah.

\section{Yusuf \& Kepemimpinannya}

\section{Kepemimpinan di Rumah}

Yusuf merupakan salah satu tokoh Perjanjian Lama yang mengalami proses pembentukan kepemimpinan pemimpin yang begitu Panjang dan sukar. Ada begitu banyak nilai-nilai yang timbul dari perjalanan Yusuf dimulai dari lingkungan keluarga, di rumah Potifar, di dalam Penjara dan di istana Mesir. Yusuf memiliki karakter dan integritas dan jujur. Yusuf memiliki perspektif jangka panjang yang tepat, bahkan saat berada di penjara karena kejahatan yang tidak dia lakukan. Selama di penjara dan di sepanjang semua kekacauan, Yusuf tetap setia kepada Tuhan dan tidak pernah goyah dari komitmennya untuk mengikuti-Nya.

Dimulai dari keluarganya sendiri, sebagai seorang anak ia adalah seorang pemimpin yang perilaku dan tindakannya menarik perhatian ayahnya sehingga membuatnya disukai. Sejak usia muda, Yusuf percaya bahwa Tuhan telah menetapkan dia untuk kebesaran. Dalam mimpi, Tuhan meyakinkan Yusuf bahwa dia akan naik ke posisi kepemimpinan atas orang tua dan saudara-saudaranya (Kej. 37:5-11). Dari sudut pandang Yusuf, mimpi-mimpi ini adalah bukti berkat ilahi, bukan ambisinya sendiri. Namun, dari sudut pandang saudarasaudaranya, mimpi-mimpi itu merupakan manifestasi lebih lanjut dari hak istimewa yang tidak adil yang dinikmati Yusuf sebagai putra kesayangan ayah mereka, Yakub (Kej. 37:3-4). Namun keberadaan Yusuf di pihak yang benar tidak membebaskan ia dari konflik dari saudara-saudaranya yang tidak memiliki pandangan yang sama. Pemimpin yang baik berusaha untuk mendorong kerja sama daripada iri hati. Kegagalan Yusuf untuk menyadari hal ini membuat dia sangat berselisih dengan saudara-saudaranya. Setelah awalnya merencanakan pembunuhan terhadapnya, saudara-saudaranya memutuskan untuk menjualnya ke karavan pedagang yang membawa barang melalui Kanaan ke Mesir. Para pedagang, pada gilirannya, menjual Yusuf kepada Potifar, "panglima penjaga" yang adalah "perwira Firaun” di Mesir (Kej. 37:36; 39:1). 
Kepemimpinan Yusuf Di Kediaman Potifar

Tugas Yusuf dalam pekerjaan Potifar memberinya berbagai tanggung jawab fidusia. Pada awalnya, Yusuf hanya "di" rumah tuannya. Kita tidak tahu dalam kapasitas apa dia melayani, tetapi ketika Potifar mengenali kompetensi umum Yusuf, dia mengangkatnya menjadi penatalayan pribadinya dan "menempatkannya untuk bertanggung jawab atas semua yang dia miliki" (Kej. 39:4).

Setelah beberapa waktu, istri Potifar tertarik secara seksual pada Yusuf (Kej. 39:7). Penolakan Yusuf terhadap uang muka istrinya sangat jelas dan masuk akal. Dia mengingatkannya akan kepercayaan luas yang diberikan Potifar kepadanya dan menggambarkan hubungan yang dia cari dalam istilah moral/agama "kejahatan" dan "dosa" (Kej. 39:9). Dia peka terhadap dimensi sosial dan teologis. Lebih jauh lagi, dia menawarkan perlawanan verbal berulang kali, dan dia bahkan menghindari kehadirannya. Ketika diserang secara fisik, Yusuf membuat pilihan untuk melarikan diri setengah telanjang daripada menyerah.

Pelecehan seksual yang dilakukan perempuan ini terjadi dalam relasi kuasa yang merugikan Yusuf. Meskipun dia percaya bahwa dia memiliki hak dan kekuatan untuk menggunakan Yusuf dengan cara ini, kata-kata dan kontaknya jelas tidak disukainya. Pekerjaan Yusuf mengharuskan dia untuk berada di rumah di mana dia berada, namun dia tidak dapat menarik perhatian Potifar tanpa mengganggu hubungan perkawinan mereka. Bahkan setelah melarikan diri dan ditangkap atas tuduhan palsu, Yusuf tampaknya tidak memiliki jalan hukum.

Segi-segi dari episode ini sangat menyentuh isu-isu pelecehan seksual di tempat kerja saat ini. Orang-orang memiliki standar yang berbeda tentang apa yang dianggap sebagai ucapan yang tidak pantas dan kontak fisik, tetapi keinginan mereka yang berkuasa adalah yang sering diperhitungkan dalam praktik. Pekerja sering diharapkan untuk melaporkan insiden pelecehan potensial kepada atasan mereka, tetapi seringkali enggan untuk melakukannya karena mereka tahu risiko kebingungan dan pembalasan. Untuk memperumit ini, bahkan ketika pelecehan dapat didokumentasikan, pekerja mungkin menderita karena telah melapor. Kesalehan Yusuf tidak menyelamatkan dia dari tuduhan palsu dan pemenjaraan. Jika kita menemukan diri kita dalam situasi paralel, kesalehan kita bukanlah jaminan bahwa kita akan lolos tanpa cedera. Tetapi Yusuf memang 
meninggalkan kesaksian yang mendidik kepada istri Potifar dan mungkin orang lain dalam rumah tangga itu. Mengetahui bahwa kita adalah milik Tuhan dan bahwa Dia membela yang lemah tentu akan membantu kita menghadapi situasi sulit tanpa menyerah. Kisah ini adalah pengakuan realistis bahwa melawan pelecehan seksual di tempat kerja mungkin memiliki konsekuensi yang menghancurkan. Namun itu juga merupakan kisah harapan bahwa dengan kasih karunia Tuhan, kebaikan pada akhirnya akan menang dalam situasi tersebut. Yusuf juga memberikan contoh bagi kita, bahwa bahkan ketika kita dituduh dan diperlakukan salah, kita melanjutkan pekerjaan yang telah Tuhan berikan kepada kita, membiarkan Tuhan memperbaikinya pada akhirnya.

\section{Kepemimpinan Yusuf di dalam Penjara}

Pelayanan Yusuf di penjara ditandai dengan kehadiran Tuhan, perkenanan sipir penjara, dan kenaikan pangkat Yusuf menjadi pemimpin (Kej. 39:21-23). Di penjara, Yusuf bertemu dengan dua pejabat Firaun yang dipenjara, kepala juru minuman dan kepala juru roti. Banyak teks Mesir menyebutkan peran juru minuman, yang tidak hanya mencicipi anggur untuk kualitas dan untuk mendeteksi racun tetapi juga yang menikmati kedekatan dengan mereka yang memiliki kekuatan politik. Mereka sering menjadi orang kepercayaan yang dihargai karena nasihat mereka (lihat Neh. 2:1-4) (Kitchen, 1996:248). Seperti kepala juru minuman, kepala pembuat roti juga merupakan pejabat terpercaya yang memiliki akses terbuka ke orang-orang tertinggi dalam pemerintahan dan yang mungkin telah melakukan tugas-tugas di luar penyiapan makanan. Di penjara, Yusuf melakukan pekerjaan menafsirkan mimpi untuk individu-individu yang terhubung secara politik ini.

Menafsirkan mimpi di dunia kuno adalah profesi canggih yang melibatkan "buku mimpi" teknis yang mencantumkan elemen mimpi dan artinya. Rekaman kebenaran mimpi masa lalu dan interpretasinya memberikan bukti empiris untuk mendukung prediksi penafsir (Harrison,1979:404). Yusuf, bagaimanapun tidak dididik dalam tradisi ini dan memuji Tuhan dengan menyediakan interpretasi yang akhirnya terbukti benar (Kej. 40:8). Dalam hal ini, juru minuman dikembalikan ke jabatan sebelumnya, dimana ia segera melupakan Yusuf.

Dinamika yang ada dalam cerita ini masih ada sampai sekarang. Jika ditarik suatu pelajaran kepemimpinan, bahkan di 
dalam penjara Yusuf berinvestasi dalam kesuksesan orang lain yang melampaui jangkauannya, namun lagi-lagi jasa Yusuf terlupakan kembali ketika kegunaannya telah dihabiskan. Apakah ini berarti bahwa pekerjaan Yusuf sia-sia, tentu dalam keadaan seperti ini Yusuf mulai terfikir bisa jadi ini merupakan momentum promosinya setelah sekian lama dalam kondisi yang dirugikan oleh orang lain. Namun pelajaran kepemimpinan kembali tampak pada jiwa Yusuf yang murni, keadaan Yusuf dalam penjara tidak lantas membuat ia menjadi orang yang patah hati dan skeptis. Bisa saja Yusuf memilih berdiam diri daripada turut dalam persolan orang lain. Terlebih lagi, Yusuf tidak memiliki cara untuk memverifikasi secara independen kisah dua pejabat di penjara. "Yang pertama menyatakan suatu perkara tampaknya benar, sampai yang lain datang dan memeriksa silang" (Ams. 18:17).

Yusuf mungkin memiliki keraguan tentang bagaimana investasi yang telah dia perbuat pada orang lain pada akhirnya dapat menguntungkan dirinya. Atau mungkin Yusuf bertanya-tanya tentang karakter dan motif orang-orang yang ia bantu. Bisa jadi Yusuf sendiri tidak setuju dengan apa yang mereka lakukan sesudahnya. Hal-hal seperti ini bahkan menjadi bervariasi dan kompleks.
Ini merupakan semangat kepemimpinan yang lahir dari spiritualitas dan moralitas yang matang. Kemauan dan keprihatinan kepada orang lain meskipun Yusuf sendiri adalah orang yang lebih memerlukan pertolongan. Namun Yusuf tidak justru menjadi pribadi yang lumpuh dalam kebaikan. Hal ini yang di dalam Perjanjian Lama ditekankan oleh rasul Paulus, "selagi ada kesempatan, marilah kita bekerja untuk kebaikan semua orang" (Gal. 6:10). Jika segala sesuatu dimulai dengan komitmen untuk bekerja bagi Tuhan di atas segalanya, maka akan lebih mudah untuk melangkah maju, percaya bahwa "dalam segala hal Tuhan bekerja untuk kebaikan mereka yang mengasihi Dia, yang dipanggil sesuai dengan tujuannya" (Rm. 8:28, NIV).

\section{Kepemimpinan Yusuf di Istana Mesir}

Dua tahun lagi berlalu sampai Yusuf memperoleh kesempatan untuk dibebaskan dari penderitaannya di penjara. Firaun mulai mengalami mimpi-mimpi yang mengganggu, dan kepala juru minuman teringat akan keterampilan pemuda Ibrani yang pernah menolong ia di penjara. Mimpi Firaun tentang sapi dan batang gandum membingungkan para penasihatnya yang paling terampil. Yusuf bersaksi tentang kemampuan Tuhan untuk memberikan 
interpretasi dan perannya sendiri hanya sebagai perantara dari wahyu ini (Kej. 41:16). Sebelum Firaun, Yusuf tidak menggunakan nama perjanjian Allah secara eksklusif untuk umatnya sendiri. Sebaliknya, ia secara konsisten menyebut Tuhan dengan istilah yang lebih umum Elohim. Dengan melakukan itu, Yusuf menghindari membuat pelanggaran yang tidak perlu, hal ini didukung oleh fakta bahwa Firaun memuji Tuhan karena mengungkapkan kepada Yusuf arti mimpi Firaun (Kej. 41:39). Di tempat kerja, terkadang orang percaya dapat memuji Tuhan atas kesuksesan mereka dengan cara yang dangkal yang akhirnya membuat orang kecewa. Namun, cara Yusuf melakukannya mengesankan Firaun, menunjukkan bahwa memuji Tuhan di depan umum dapat dilakukan dengan cara yang dapat dipercaya.

Kehadiran Tuhan dengan Yusuf begitu jelas sehingga Firaun mengangkat Yusuf menjadi orang kedua di Mesir, terutama untuk mengambil alih persiapan menghadapi kelaparan yang akan datang (Kej. 41:37-45). Di dalam ayat ini termaktub seluruh kunci berkat Allah, demikian terjadi dalam kehidupan Yusuf seperti yang Tuhan pernah ucapkan kepada Abraham. "Aku akan memberkati mereka yang memberkati kamu ... dan di dalam kamu semua keluarga di bumi akan diberkati” (Kej. 12:3). Seperti Yusuf, ketika ia mengakui ketidakmampuannya sendiri untuk menghadapi tantangan yang dihadapi dan menemukan cara yang tepat untuk menghubungkan kesuksesan dengan Tuhan, Yusuf sekali lagi membawa suatu bentuk kepemimpinan naik ke level yang lebih tinggi yang membentuk pertahanan yang kuat terhadap kesombongan yang sering menyertai pujian publik.

Promosi Yusuf memberinya perlengkapan kepemimpinan yang signifikan: cincin meterai kerajaan dan rantai emas, pakaian bagus yang sesuai dengan jabatan tingginya, transportasi resmi, nama Mesir baru, dan istri Mesir dari keluarga kelas atas (Kej. 41:41-45). Walaupun pernah ada godaan untuk meninggalkan warisan Ibraninya. Tuhan membantu Yusuf menghadapi kegagalan dan kekalahan, namun Yusuf juga memberikan pelajaran penting bahwa kepemimpinan dalam aspek lain mungkin lebih membutuhkan pertolongan Tuhan ketika menghadapi kesuksesan. Teks tersebut menyajikan beberapa indikasi tentang bagaimana Yusuf menangani kenaikan pangkatnya dengan cara yang saleh. Sebagian dari ini berkaitan dengan persiapan Yusuf sebelum promosinya. Sebagaimana di tulis Kaukahe 
dan Widjaja (Kaukahe \& Widjaja, 2020) yang dikutip dari sebuah literatur tua yang ditulis oleh Jephet Ibn Ali The Karaite menyebutkan bahwa alasan "roh yang luar biasa" yang membuat Yusuf di promosikan oleh Firaun di Mesir (Kej. 41:38).

Kembali ke rumah ayahnya, visi yang Tuhan berikan kepada Yusuf melalui mimpi meyakinkan Yusuf bahwa dia memiliki tujuan yang telah ditetapkan secara ilahi yang tidak pernah dia lupakan. Sifat pribadinya pada dasarnya mempercayai orang. Dia tampaknya tidak menyimpan dendam terhadap saudara-saudaranya yang cemburu atau juru minuman yang pelupa. Sebelum Firaun mempromosikannya, Yusuf tahu bahwa Tuhan menyertainya dia telah membuktikannya. Dalam setiap kegagalan yang direka-rekakan kepadanya Yusuf tidak lantas luntur dalam memuji, bahkan setiap keahlian yang dimiliki pada akhirnya mengingatkan Yusuf sendiri bahwa semuanya berasal dari Tuhan. Yusuf sopan dan rendah hati, menunjukkan keinginan untuk melakukan apa pun yang dia bisa untuk membantu Firaun dan orang-orang Mesir. Bahkan ketika orang Mesir kehilangan mata uang dan ternak, Yusuf mendapatkan kepercayaan dari rakyat Mesir dan Firaun sendiri (Kej. 41:55). Sepanjang sisa hidupnya sebagai pemimpin sekaligus, manajer dan administrator, Yusuf secara konsisten mengabdikan dirinya untuk manajemen yang efektif demi kebaikan orang lain.

Kisah Yusuf sampai saat ini mengingatkan kita bahwa di dunia kita yang hancur, jawaban Tuhan atas doa-doa kita tidak serta merta datang dengan cepat. Yusuf berusia tujuh belas tahun ketika saudarasaudaranya menjualnya sebagai budak (Kej. 37:2). Pembebasan terakhirnya dari penawanan terjadi ketika dia berusia tiga puluh (Kej. 41:46), tiga belas tahun kemudian Yusuf segera melakukan pekerjaan yang telah ditetapkan Firaun untuknya. Minat utamanya adalah menyelesaikan pekerjaan untuk orang lain, daripada mengambil keuntungan pribadi dari posisi barunya sebagai kepala istana. Dia mempertahankan imannya kepada Tuhan, memberi anak-anaknya nama yang memuji Tuhan karena menyembuhkan rasa sakit emosionalnya dan membuatnya berbuah (Kej. 41:51-52). Dia menyadari bahwa hikmat dan ketajamannya adalah karunia dari Tuhan, tetapi bagaimanapun dia masih harus banyak belajar tentang tanah Mesir, khususnya industri pertaniannya. Sebagai administrator senior, pekerjaan Yusuf menyentuh hampir setiap bidang praktis kehidupan bangsa. Kantornya akan 
mengharuskan dia belajar banyak tentang undang-undang, komunikasi, negosiasi, transportasi, metode penyimpanan makanan yang aman dan efisien, pembangunan, penyusunan strategi dan peramalan ekonomi, pencatatan, penggajian, penanganan transaksi baik dengan mata uang maupun melalui barter, sumber daya manusia, dan akuisisi real estat. Kemampuannya yang luar biasa sehubungan dengan Tuhan dan manusia tidak beroperasi dalam domain yang terpisah.(Enlow, 2009:69-111). Kejeniusan keberhasilan Yusuf terletak pada integrasi yang efektif dari karunia ilahi dan kompetensi yang diperolehnya. Bagi Yusuf, semua ini adalah pekerjaan yang saleh.

Firaun telah mencirikan Yusuf sebagai orang yang "cerdas dan bijaksana" (Kej 41:39), dan sifat-sifat ini memungkinkan Yusuf melakukan pekerjaan perencanaan dan administrasi strategis. Kata-kata Ibrani untuk bijak dan hikmat (hakham dan hokhmah) menunjukkan tingkat pemahaman mental yang tinggi, tetapi juga digunakan untuk berbagai keterampilan praktis termasuk pengerjaan kayu, batu mulia, dan logam (Kel. 31:3-5; 35:31-33), menjahit (Kel 28:3; 35:26, 35), serta administrasi (U1 34:9; 2 Taw 1:10) dan keadilan hukum (1 Raj 3:28). Keterampilan ini juga ditemukan di antara orang-orang yang tidak percaya, tetapi orang-orang bijak dalam Alkitab menikmati berkat khusus dari Allah yang bermaksud agar Israel menunjukkan jalan Allah kepada bangsabangsa (Ul 4:6).

Sebagai tindakan pertamanya, "Yusuf...melintasi seluruh tanah Mesir" (Kej. 41:46) dalam sebuah perjalanan inspeksi. Dia harus mengenal orang-orang yang mengelola pertanian, lokasi dan kondisi ladang, tanaman, jalan, dan alat transportasi. Tidak dapat dibayangkan bahwa Yusuf dapat menyelesaikan semua ini pada tingkat pribadi. Dia harus mendirikan dan mengawasi pelatihan yang setara dengan Departemen Pertanian dan Pendapatan. Selama tujuh tahun panen berlimpah, Yusuf menyimpan gandum di kota-kota (Kej 41:4849). Selama tujuh tahun masa paceklik berikutnya, Yusuf membagikan gandum kepada orang Mesir dan orang lain yang terkena dampak kelaparan yang meluas. Untuk menciptakan dan mengelola semua ini, sambil bertahan dari intrik politik monarki absolut, diperlukan bakat luar biasa.

Kecerdasan Sosial Yusuf (Kejadian 47:1326)

Setelah orang-orang kehabisan uang, Yusuf mengizinkan mereka untuk menukar ternak mereka dengan makanan. Rencana ini 
berlangsung selama satu tahun di mana Yusuf mengumpulkan kuda, domba, kambing, sapi, dan keledai (Kej. 47:15-17). Dia harus menentukan nilai hewan-hewan ini dan membangun sistem pertukaran yang adil. Ketika makanan langka, orang-orang terutama mengkhawatirkan kelangsungan hidup diri mereka sendiri dan orang yang mereka cintai. Menyediakan akses ke titik distribusi makanan dan memperlakukan orang dengan adil menjadi urusan administrasi yang sangat penting. Yusuf peka terhadap sengsara orang Mesir oleh karena itu ia bertindak Membebaskan Kemiskinan Rakyat Mesir. Kepemimpinan Yusuf sesuai dengan apa yang di tulis Sanjaya dkk (Ginting et al., 2020) yaitu corak kepemimpinan yang kaya akan sifat sifat positip ini, bergerak menuju suatu sasaran yang pasti berdasarkan perencanaan yang mantap dan bukannya sekedar reaksi emosionil terhadap situasi dan lingkungan, namun berjalan dalam proses yang matang dan terarah.

Ketika semua ternak telah diperdagangkan, orang-orang dengan rela menjual diri mereka sebagai budak kepada Firaun dan menjualnya juga kepemilikan tanah mereka (Kej. 47:18-21). Dari perspektif kepemimpinan, ini pasti sangat mengerikan untuk disaksikan. Yusuf, bagaimanapun, mengizinkan orang-orang untuk menjual tanah mereka dan masuk ke dalam perbudakan, tetapi dia tidak mengambil keuntungan dari mereka dalam ketidakberdayaan mereka. Yusuf harus memastikan bahwa sifat-sifat ini dinilai dengan benar sebagai ganti benih yang akan ditanam (Kej. 47:23). Dia memberlakukan hukum abadi bahwa orang mengembalikan 20 persen dari panen ke Firaun. Ini memerlukan pembuatan sistem untuk memantau dan menegakkan kepatuhan masyarakat terhadap hukum dan membentuk departemen yang didedikasikan untuk mengelola pendapatan. Dalam semua ini, Yusuf membebaskan keluarga imam dari menjual tanah mereka karena Firaun memberi mereka jatah makanan yang tetap untuk memenuhi kebutuhan mereka secara memadai (Kej. 47:22, 26). Penanganan populasi khusus ini akan memerlukan sistem distribusi yang lebih kecil dan berbeda yang disesuaikan untuk mereka.

Kemiskinan dan konsekuensinya adalah realitas ekonomi. Peran Yusuf dalam kepemimpinannya disini sangat jelas, memberantas kemiskinan, demikian juga sebagai orang kita tidak dapat mengharapkan kesuksesan penuh sampai kerajaan Tuhan digenapi. Orang percaya mungkin tidak memiliki kekuatan untuk menghilangkan 
keadaan yang mengharuskan orang membuat pilihan sulit, tetapi kita dapat menemukan cara untuk mendukung orang-orang saat mereka atau mungkin kita sendiri mengatasinya. Memilih yang lebih kecil konsekuensinya mungkin merupakan pekerjaan yang perlu dan dapat menghancurkan secara emosional. Dalam pekerjaan kita, kita mungkin mengalami ketegangan yang timbul dari perasaan empati terhadap yang membutuhkan, namun memikul tanggung jawab untuk melakukan apa yang baik bagi orang-orang dan organisasi tempat kita bekerja. Yusuf mengalami tuntunan Tuhan dalam tugastugas yang sulit ini, seperti janji Tuhan bagi orang-orang pilihan-Nya "Aku tidak akan pernah meninggalkanmu atau mengabaikanmu" (Ibr. 13:5).

\section{Memimpin dengan Kebijaksanaan Penuh}

Pada akhirnya Yusuf bukan hanya hanya memiliki kebijaksanaan yang besar namun juga mampu menerapkan keterampilan dan hikmat yang diberikan Tuhan, Yusuf berhasil membawa Mesir melewati bencana pertanian. Ketika tujuh tahun panen yang baik datang, Yusuf mengembangkan sistem penimbunan untuk menyimpan biji-bijian untuk digunakan selama kekeringan yang akan datang. Ketika tujuh tahun kekeringan tiba, "Yusuf membuka Gudang" dan menyediakan makanan yang cukup untuk membawa bangsa itu melewati kelaparan. Strateginya yang bijaksana dan implementasi rencana yang efektif bahkan memungkinkan Mesir untuk memasok gandum ke seluruh dunia selama kelaparan (Kej. 41:57). Dalam hal ini, pemenuhan janji Tuhan bahwa keturunan Abraham akan menjadi berkat bagi dunia terjadi tidak hanya untuk kepentingan bangsa asing, tetapi bahkan melalui industri bangsa asing, Mesir.

Sebenarnya, berkat Tuhan bagi orang Israel datang hanya setelah dan melalui berkat-Nya dari orang asing. Tuhan tidak membangkitkan seorang Israel di tanah Israel untuk menyediakan bantuan bagi Israel selama kelaparan. Sebaliknya, Allah memampukan Yusuf, yang bekerja di dalam dan melalui pemerintah Mesir, untuk memenuhi kebutuhan bangsa Israel (Kej. 47:11-12). Meskipun di puncak kepemimpinan Yusuf, tetaplah ada celah yang tidak ideal dalam kepemimpinannya. Sebagai pejabat dalam masyarakat yang terkadang represif, ia menjadi bagian dari struktur kekuasaannya, dan ia secara pribadi memberlakukan perbudakan pada banyak orang (Kej. 47:21). 


\section{Kepemimpinan \& Persaudaraan Yusuf}

Pengujian watak kepemimpinan Yusuf puncaknya kembali Allah pertemukan dalam reuni bersama saudara-saudara. Bagaimanapun Kejadian 4 menggambarkan suatu narasi persaudararaan yang gagal namun Allah ingin Yusuf dapat membereskan hal itu bukan hanya di pihak Yusuf sendiri tetapi juga di pihak saudarasaudaranya. Hal ini sangat penting karena akan memungkinkan Yusuf untuk menjalin hubungan yang harmonis dengan saudarasaudara yang telah berbuat jahat kepada dia. Yusuf menenangkan saudara-saudaranya yang ketakutan dengan menunjuk pada pekerjaan Tuhan yang bertanggung jawab untuk menempatkan Yusuf sebagai penanggung jawab seluruh Mesir (Kej. 45:8). Waltke menjelaskan pentingnya interaksi antara Yusuf dan saudarasaudaranya: Adegan ini memperlihatkan anatomi rekonsiliasi. Ini tentang kesetiaan kepada anggota keluarga yang membutuhkan, bahkan ketika dia terlihat bersalah; memuliakan Allah dengan mengakui dosa dan konsekuensinya; mengabaikan favoritisme; menawarkan diri untuk menyelamatkan orang lain; menunjukkan cinta sejati dengan tindakan pengorbanan nyata yang menciptakan konteks kepercayaan; membuang kendali dan kekuatan pengetahuan demi keintiman; merangkul belas kasih yang mendalam, perasaan lembut, kepekaan, dan pengampunan; dan berbicara satu sama lain. Sebuah keluarga disfungsional yang memungkinkan kebajikan ini untuk merangkulnya akan menjadi terang bagi dunia (Waltke, 2001:565-66).

\section{Aplikasi dari Pengalaman Kepemimpinan} Yusuf Bagi Gereja Di Masa Kini (Kejadian 41:46-57; 47:13-26)

Berdasarkan seluruh pemaparan kehidupan Yusuf yang sudah penulis kemukakan di atas, maka hal yang sangat penting yang penulis sampaikan melalui bagian berikut ini adalah, bagaimana caranya Gereja mengimplementasikan spritualitas dan moralitas yang begitu seimbang dan relevan dalam kepemimpinan di berbagai lini.

Yusuf menjalani kehidupan yang penuh integritas dan setia kepada Tuhan di tengah-tengah kemakmuran dan kesulitan. Dia adalah teladan dan figur yang bagus untuk dicontoh. Bahkan kehidupan Yusuf mengajarkan kita bahwa kekecewaan sangat penting untuk pertumbuhan rohani karena mereka menuntut iman dan meletakkan semua harapan kepada Tuhan. Yusuf pasti telah memercayai Tuhan dengan emosinya 
ketika dia berhadapan muka dengan orangorang yang telah sangat menyakitinya. Yusuf percaya bahwa Tuhan tetap memegang kendali bahkan ketika tampaknya dunianya berada di luar kendali pribadinya. Hal ini menunjukkan tingkat kematangan spiritualitas Yusuf yang sudah terbentuk di usia yang masih terbilang sangat muda.

Pemimpin Kristen yang sejati harus memiliki spiritualitas yang utuh. Spiritualitas berarti memahami Tuhan melalui konflik di dalam diri atau konflik dengan orang lain kemudian menemukan makna mendalam yang ingin Tuhan atau semesta sampaikan pada diri. Seorang Pemimpin semestinya memiliki kesadaran diri, mengetahui apa yang menjadi nilai dalam hidupnya, apa yang dia percayai, dan apa yang memotivasinya.

Dalam perbedaan karakter Yusuf dan saudara-saudaranya, ia mampu memiliki dan berpegang teguh pada keyakinan sendiri yang mungkin berbeda dari kebanyakan karakter saudara-saudaranya (Kejadian 37:2). Bahkan Yusuf terbukti mampu mengatasi masalah sesuai prinsip dan keyakinan yang dipegangnya, sekalipun melalui berbagai persoalan dan masalah. Yusuf mampu melihat lebih jauh secara dewasa bahwa tantangan hidup yang dia alami berulang-ulang bukan bentuk hukuman dari Tuhan tetapi semata-mata merupakan bagian dari pembetukan hidupnya untuk menjadi seorang pemimpin di masa mendatang.

Dalam Hal moralitas sendiri Yusuf tampak teruji. Sebagaimana diceritakan dalam narasi Kejadian pasal 37 di atas tampaknya Yusuf memiliki hati nurani yang peka untuk mengetahui apa yang benar dan salah. Jika rahasia dari penyertaan Allah dalam kehidupan Yusuf menjadi tolok ukur keberhasilannya, itu mungkin karena di sisi lain ia belajar untuk takut akan Tuhan.

Sejalan dengan seluruh pemaparan di atas terkait kepemimpinan Yusuf yang luar biasa dapat diperoleh beberapa aplikasi praktis bagi gereja melalui pengalaman kepemimpinan Yusuf:

1. Yusuf senantiasa tidak putus asa melakukan pekerjaan dengan baik bahkan terlepas itu menguntungkan atau tidak menguntungkan dirinya

2. Yusuf menyadari segala keadaan yang ada dalam kehidupan adalah semuanya merupakan tanggungjawab Allah sejak semula

3. Mempercaya Visi Allah dalam hidupnya sekaligus mempercayakan hidupnya bagi Allah dengan moral yang baik.

4. Yusuf memiliki komitmen yang kuat kepada Allah mengenai masa depannya, walaupun awalnya hanya sebatas visi. 
5. Yusuf mengijinkan Allah mengarahkan dirinya kepada rencana Allah.

6. Yusuf selalu memiliki kemurahan yang nyata terlepas dia berada dan dalam keadaaan apapun.

7. Yusuf senantiasa adil dalam segala perkara, bahkan saat dalam keadaan yang paling sukar sekalipun.

8. Yusuf Hidup saleh dan terhormat.

9. Yusuf berhasil meneruskan kebaikan Allah dalam dirinya seluas-luasnya bagi orang-orang yang membutuhkan, tanpa terjebak dalam sikap kecewa ketika ia dilupakan.

10. Persis seperti Yusuf, Tuhan tidak pernah membawa kita dalam suatu perjalanan panggilan yang sama sekali tanpa tantangan. Yusuf menyadari bahwa tantangan itu bukan bentuk hukuman dari Tuhan tapi proses pembentukan kepemimpinan.

11. Yusuf melakukan Tugas yang Tuhan percayakan kepadanya dengan penuh tanggun jawab.

12. Yusuf mempercayai bahwa apa yang ia lakukan tidak hanya akan bermanfaat bagi mereka yang ia lihat dan temui, tetapi juga bahwa pekerjaan tersebut berpotensi menyentuh kehidupan bagi banyak generasi yang akan datang. Allah dapat melakukan jauh lebih banyak daripada yang dapat kita doakan atau bayangkan (Ef. 3:20).

\section{KESIMPULAN}

Berdasarkan seluruh pemaparan di atas dapat disimpulkan bahwa kepemimpinan Yusuf menjadi salah satu tolok ukur kepemimpinan paling berhasil dalam sejarah Perjanjian Lama, Perjalanan kepemimpinan Yusuf begitu praktis menjadi model berharga sebagai pelajaran yang baik bukan hanya bagi individu dalam posisi kepemimpinan tetapi semua orang yang ingin meningkatkan karakter mereka. Perjalanan Kepemimpinan Yusuf sendiri sarat akan nilai spiritualitas dan moralitas yang bersumber dari Allah sendiri. Kepemimpinan Yusuf juga sekaligus menjadi tanda kehadiran Allah bekerja dengan umat manusia yang sewajarnya bagi kepemimpinan Kristen hal ini sebagai tanda orang percaya dalam menunaikan amanat agung Allah dalam Panggilan Allah yang progresif melalui Abraham sampai kepada Kristus. Bukan berarti bahwa kepemimpinan Yusuf telah sempurna dan ideal, namun Yusuf telah meninggalkan napak tilas kepemimpinan yang penting untuk gereja dan umat Tuhan yang kan melanjutkan estafet kepemimpinan tersebut di berbagai aspek di masa kini. Penelitian ini juga 
diharapkan dapat menjadi referensi bagi peneliti selanjutnya yang tertarik untuk menganalisis Misi Allah bagi Israel dan Bangsa-bangsa melalui kepemimpinan Yusuf. Penelitian ini diharapkan dapat memperkaya studi tentang kepemimpinan, khususnya kajian Kepemimpinan Melalui tokoh-tokoh baik dalam Perjanjian Lama maupun Perjanjian Baru.

\section{DAFTAR PUSTAKA}

Borba, M. (2001). Membangun Kecerdasan Moral. PT Gramedia Pustaka Utama.

Decker, L. R. (1993). The Role of Trauma in Spiritual Development. Journal of Humanistic Psychology, 33(4), 33-46. https://doi.org/10.1177/002216789303 34004

Dwiraharjo, S. (2018). Analisis Historis Kejadian $\quad 37-50 \quad$ Tentang Visi Kepemimpinan Yusuf. Prudentia: Jurnal Teologi Dan Pendidikan Kristiani, 1(2), 94-107.

Ganje-Fling, M. A., \& McCarthy, P. (1996). Impact of Childhood Sexual Abuse on Client Spiritual Development: Counseling Implications. Journal of Counseling \& Development, 74(3), 253-258.

https://doi.org/10.1002/j.1556-

6676.1996.tb01861.x
Ginting, D., Sanjaya, Y., \& Widjaja, F. I. (2020). Kepemimpinan Kristen: Leader sebagai Kualifikasi Kepemimpinan Nehemia. Real Didache, 5(1), 71-79. https://doi.org/10.31219/osf.io/vchns

Harrison, R. K. (1979). "Baker," in The International Standard Bible Encyclopedia (G. W. Bromiley (ed.)). Eerdmans.

Hendi, H. (2017). Empat Peristiwa Penting Di dalam Kehidupan Yusuf: Sebuah Kajian Terhadap Kecerdasan Yusuf. DUNAMIS: Jurnal Penelitian Teologi Dan Pendidikan Kristiani, 2(1), 29. https://doi.org/10.30648/dun.v2i1.130

Hover, M. (1999). The psychology of religion and coping: theory, research, practice. Psycho-Oncology, 8(5), 460461.

https://doi.org/10.1002/(SICI)1099-

1611(199909/10)8:5<460::AID-

PON416>3.0.CO;2-V

Jones, G., Hanton, S., \& Connaughton, D. (2007). A framework of mental toughness in the world's best performers. Sport Psychologist, 21(2). https://doi.org/10.1123/tsp.21.2.243

Jones, G., Hanton, S., \& Connaughton, D. (2002). What is this thing called mental toughness? An investigation of elite sport performers. Journal of Applied 
Sport Psychology, 14(3).

https://doi.org/10.1080/104132002901

03509

Kaukahe, P. T., \& Widjaja, F. I. (2020). Karakteristik Kepemimpinan Pentakostal-Karismatik: Refleksi Daniel 6:4. Diegesis, 3(2), 82-90.

King, M., Speck, P., \& Thomas, A. (1995).

The Royal Free Interview for Religious and Spiritual Beliefs: development and standardization. Psychological Medicine, 25(6), 1125-1134. https://doi.org/10.1017/S00332917000 33109

Kitchen, K. A. (1996). “Cupbearer,” in New Bible Dictionary (I. H. Marshall, A. R. Millard, J. I. Packer, \& D. J. Wiseman (eds.)). InterVarsity Press.

Luther, M. (2007). Luther's Works, Vol. 7: Lectures on Genesis, Chapters 38-44. Concordia Publishing House.

Mathews, K. A. (2007). Genesis 11:2750:26, The New American Commentary 1B. Broadman \& Holman Publishers.

Matthew, K. A. (2005). The New American Commentary: Genesis 11:27-50:26. Broadman \& Holman Publishers.

Purwanto, A. (2020). Tinjauan Kecerdasan Yusuf Berdasarkan Kecerdasan Spiritual (Spiritual Intelligence), Kecerdasan Emosional (Emotional
Intelligence), Kecerdasan Intelektual (Intellectual Intellegence) Dan Ketangguhan (Adversity Quotient). Shift Key: Jurnal Teologi Dan Pelayanan, 10(1), 75-93. https://doi.org/10.37465/shiftkey.v10i1 .74

Rad, G. von. (1959). Genesis: A Commentary. The Westminster Press.

Riswanto, D., \& Djadi, J. (2010). PrinsipPrinsip Kepemimpinan Yusuf Dalam Menghadapi Perubahan Berdasarkan Kitab Kejadian 37-50. Jurnal Jaffray, $8(2)$, 48. https://doi.org/10.25278/jj71.v8i2.46

Shafranske, E. P. (1996). Religion and the clinical practice of psychology. American Psychological Association. Sharma, P., Charak, R., \& Sharma, V. (2009). Contemporary perspectives on spirituality and mental health. Indian Journal of Psychological Medicine, 31(1), 16. https://doi.org/10.4103/02537176.53310

Simanjuntak, F., Marisi, C. G., Lahagu, A., Purba, B. M. M., \& Sihombing, A. (2018). Membangun Spiritualitas Kristen Warga Binaan di Lapas Umum Kelas II A Tanjungpinang. REALCOSTER:Jurnal Pengabdian Kepada Masyarakat, 1(1), 6-10. 
Spero, S. (1983). Morality, Halakha, and the Jewish Tradition. KTAV Publishing House.

Waltke, B. K. (2001). Genesis: A Commentary. Zondervan.

Widjaja, F. I., Abraham, R. A., Simanjuntak, F., Boiliu, N. I., \& Harefa, O. (2021). Fruit in the unfruitful season: A case study of the Indonesian Bethel Church's response to the COVID-19 pandemic. Verbum et Ecclesia, 42(1). https://doi.org/10.4102/ve.v42i1.2247

Wigglesworth, C. (2006). Why Spiritual Intelligence Is Essential to Mature Leadership by Cindy Wigglesworth Abstract. Conscious Pursuits, Inc.

Zinnbauer, B. J., Pargament, K. I., \& Scott, A. B. (1999). The Emerging Meanings of Religiousness and Spirituality: Problems and Prospects. Journal of Personality, 67(6), 889-919. https://doi.org/10.1111/1467-

6494.00077 